\title{
Exploring the limits to continued growth
}

\section{Washington}

WITH both Congress and the Bush Administration determined to limit spending on the indirect costs of research, and growth in the National Institutes of Health (NIH) budget constrained under the budget agreement between the two arms of federal government, 1991 might not seem the best time for US biomedical research centres to expand. Yet expansion is exactly what many institutes across the United States are planning, to the alarm of several Washington-based biomedical research policy groups.

Federal government spending on biomedical research has grown steadily over the past decade, from less than $\$ 5,000$ million in 1980 to today's annual budget of around $\$ 10,000$ million. But the harsh financial reality of the US budget deficit means that this growth is now likely to slow, at least temporarily. Ed Stammler, vice president of the Association of American Medical Colleges (AAMC), is concerned that the expansion plans of his member colleges will, in total, greatly exceed the resources available for biomedical research over the coming few years. "I hate to make the comparison," he says, "but how many McDonalds can you build? There's probably some limitation on the hamburger market." AMC has already launched a pilot study to assess just how over-ambitious the plans of its members are.

The Association of Academic Health Centers (AAHC) is similarly concerned. The priority for its science policy taskforce over the next 12 months is to examine how AAHC members can raise money for capital investment in new buildings and equipment in the face of the current financial difficulties. AAHC president Roger Bulger is especially worried about the fallout from the current indirect research costs scandal on investment in medical schools in the state university system. Throughout the 1960s and the 1970 s, he notes, state legislatures made the expansion of their medical schools a matter of public policy. But with the current scrutiny of indirect costs revealing the extent of federal support for capital investment in state schools, says Bulger, state legislatures are saying: "Why should we do it?"

The arguments of AAHC and AAMC assume that the predicted shortfall in investment in new biomedical research facilities and in research grant support will not be made up by private foundations and by the pharmaceutical industry, as has happened in Britain to a certain extent over the past decade. But that seems a reasonable supposition. The only significant charitable player in the US biomedical research funding field, the Howard Hughes Medical Institute, now plans to keep its spending at a steady level, after five years of growth. And David Korn, dean of Stanford Medical School, says he does not see industry "champing at the bit to join the fray".

The concern of the Washington-based umbrella organizations is noted, but swiftly dismissed by most of their member schools. Some medical school

\section{Philadelphia: US biomedicine in microcosm}

Jefferson Medical College epitomizes the research expansion witnessed at many US medical schools over the past decade. Languishing in the lower ranks of US biomedical research centres in the late 1970s, the school has pulled itself up by its bootstraps and now boasts a healthy reputation for research.

Yet a broader look at Jefferson's home city, Philadelphia, reveals the difficulties that may face medical research centres that are less successful in the race to expand. Jefferson's latest coup - the recruitment of cancer geneticist Carlo Croce, pharmacologist Gerald Litwack and an entourage of some 200 principal investigators, postdocs, graduate students, technicians and administrators was won at the expense of neighbouring Temple University's Fels Institute. Robbed of its best researchers, and with its host university in financial crisis. Fels faces an uncertain future.

Jefferson's rise to prominence was engineered in large part by its charismatic dean, Joseph Gonnella. An Italian native, Gonnella embarked on an aggressive policy of expansion and acquisition in research from the early 1980 s. The first major victory came in 1985 , with the recruitment of Darwin Prockop, the collagen biochemist, from Rutgers. Others soon followed. Having consolidated Jefferson's research into connective tissue, Gonnella moved on to pathology, luring Emanuel Rubin and his research team from Hahnemann University, also in Philadelphia.

The latest wave of expansion was

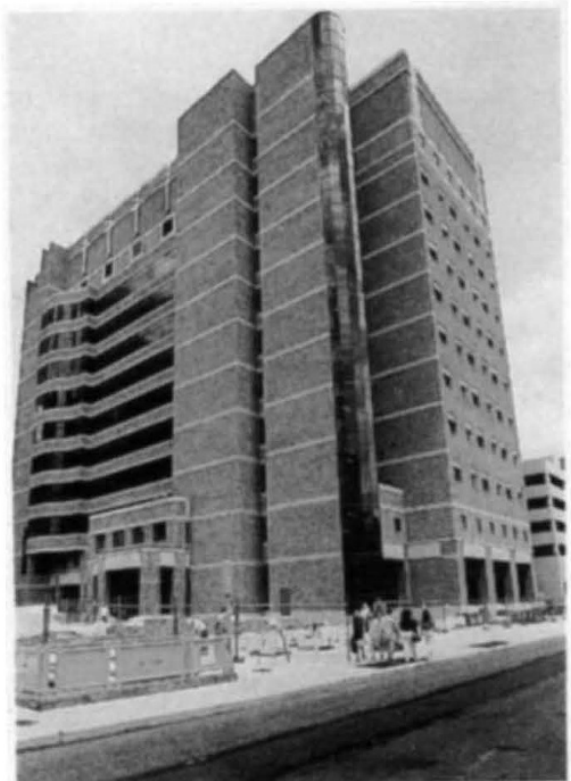

Jefferson's new $\$ 80$ million building

made possible only by the construction of a new $\$ 80$ million building. The defection of Croce and his colleagues from Temple's Fels Institute to Jefferson has caused bitter recrimination between the two institutions, but Croce's decision to move is perhaps understandable. In sharp contrast to Jefferson's gleaming new facilities and relative opulence, Fels is situated in a run-down area of Philadelphia.

Allen Myers, dean of Temple's medical school, does not believe that Croce's departure will be a mortal blow for the Fels Institute. "We're not standing still," he says, adding that a new director should be appointed in the autumn. Temple's administration is reported to be prepared to pay for the rescue of Fels, but other medical researchers in Philadelphia believe Myers faces a difficult task. Croce says that similar promises of investment were made to him when he was lured to Fels from the Wistar Institute several years ago, but that Temple never did as much as had been agreed.

Gonnella attributes Jefferson's success to a focused policy of expansion concentrating on defined areas of research - and to the medical college's strength in providing clinical care for the residents of Philadelphia. Jefferson's finances were boosted during the 1980s by a change in the Medicare payment system. Until the early 1980s, hospitals were reimbursed for the full cost of treating Medicare patients. But under the 'prospective payment' system, a set fee is paid for each treatment. The result is that hospitals, such as Jefferson, that treat patients more cheaply and efficiently can pocket the change. In Jefferson's case, these profits have been ploughed into research infrastructure.

So is Gonnella trimming back his expansion plans in the light of the current limits to the US biomedical research budget? "The 1990s will be more difficult", he concedes, but Gonnella believes Jefferson's rise will be inexorable. Already, he has targeted neurosciences as the next area for conquest. P.A. 